\title{
Conceptions of Critical Thinking from University EFL Teachers
}

\author{
Matias A. Marin ${ }^{1} \&$ Luisa de la Pava ${ }^{1}$ \\ ${ }^{1}$ Language Center, Catholic University of Manizales, Manizales, Colombia \\ Correspondence: Matias A. Marin, Ave. Santander, Cra 23 60-63, Language Center, Catholic University of \\ Manizales, Manizales, Colombia. Tel: 57-311-374-9076. E-mail: mmarin@ucm.edu.co;
} matias.marin@hotmail.com

Received: April 2, 2017 Accepted: May 28, 2017 Online Published: May 31, 2017

doi: 10.5539/elt.v10n7p78 URL: http://doi.org/10.5539/elt.v10n7p78

\begin{abstract}
Critical Thinking has become an educational and social ideal. English as a Foreign Language (EFL) teaching has not been apart from the discussion on the importance of implementing Critical Thinking into the educational process. However, research on Critical Thinking has broadly been carried out in other fields of knowledge rather than in EFL. Therefore, this study aimed to comprehend the conceptions university English teachers had about Critical Thinking in order to get a wider understanding on the way it has been conceived in EFL in relation to its concept, traits, promotion and assessment. Content Analysis, as a qualitative process of analysis and source of information, interpretations and conclusions, was the method adopted. The software Atlas.ti was the tool implemented to analyze the information. The results revealed that there is some agreement on the conception of Critical Thinking as a set of cognitive skills for problem-solving and reflective learning. Nevertheless, EFL teachers brought about their deficiency in understanding on what Critical Thinking entails. Thus, they emphasized the need of training on topics such as teaching, learning, didactics, methodology, strategies and resources to foster Critical Thinking in EFL. Based on teachers' participation in this study and the literature consulted, it was concluded that Critical Thinking in EFL is compound of communicative competence, creativity, argumentation, problem-solving, decision-making, autonomous learning, metacognition and emotions.
\end{abstract}

Keywords: conception, cognitive skills, critical thinking, EFL, metacognition, problem solving

\section{Introduction}

The English as a Foreign Language (EFL) classroom has been thought to be a great scenario to develop $21^{\text {st }}$ Century skills such as, critical thinking (CT), creativity, communication, collaboration, ICT literacy, leadership and responsibility, as well as social and cross cultural skills. Consequently, EFL directors, scholars and editors are impelling teachers to foster these skills in their lessons, specially, critical thinking. CT is regarded as one of the most essential and crucial factors of success in the 21 st century (Zhou, Jiang, \& Yao, 2015). However, it seems that the term has also become a buzzword, or at least a confusing concept among educators, since, as Facione (2011) states, "at one level we all know what critical thinking means - it means good thinking, almost the opposite of illogical, irrational thinking. But when we test our understanding further, we run into questions" (p. 2), for instance, is critical thinking the same as higher order thinking skills (HOTS)? Is it similar to creative thinking? Does it focus on the content, or on the mental process you use? Does it have general or specific applications?

Most studies on CT in EFL have cited works by Richard Paul, Linda Elder and Peter Facione who have stood out in researching and theorizing about CT skills and dispositions. Nevertheless, exploration of alternative and complementary standpoints might have been disregarded, in particular, the concept of Critical Thinking as a domain-specific mode of thinking.

The present study aimed to comprehend the conceptions university English teachers from Manizales, Colombia, had about Critical Thinking in order to get a wider understanding on the way it has been conceived in EFL in relation to its concept, traits, promotion and assessment. Therefore, this paper purports to provide a wider scope on CT in EFL based on the literature consulted and the conceptions of a group of university English teachers, as a microcosm of the EFL community, related to the meaning of critical thinking and its implications.

\section{Literature Review}

Critical Thinking is a multi-faceted concept with particular nuances from the branches of knowledge that have 
devoted time and efforts to reflect on its meaning. This chapter breaks the discussion of critical thinking into three stages: a) Most representative authors, b) Latin American authors, c) EFL authors.

\subsection{Most Representative Authors}

Paul and Elder (2007), from the Foundation for Critical Thinking, define CT as "the art of analyzing and evaluating thinking with a view to improving it" (p. 4) for the quality of our life depends on the quality of our thinking. In addition, excellence in thought must be systematically cultivated. Consequently, "CT is self-directed, self-disciplined, self-monitored, and self-corrective thinking" (p. 4).

Facione (2011) agrees on the importance of the development of thinking for our quality of life. He also expresses that being educated and practicing good judgment does not guarantee happiness or economic success, but it certainly provides more opportunities to reach these goals. Furthermore, he emphasizes that failures of critical thinking contribute to patient deaths, job loss, ineffective law enforcement, combat casualties, bad decisions, unplanned pregnancies, heart disease, academic failure, etc. (p. 3).

Facione (1990) was the principle investigator who researched Critical Thinking for purposes of educational assessment and instruction through the Delphi Method, which eventually became the Delphi Report, reaching expert consensus on CT among forty-six professional panelists. Paul, Ennis and Norris were some of the experts who participated in this study. The expert consensus stated their definition of CT as follows:

"We understand critical thinking to be purposeful, self-regulatory judgment which results in interpretation, analysis, evaluation, and inference, as well as explanation of the evidential, conceptual, methodological, criteriological, or contextual considerations upon which that judgment is based. CT is essential as a tool of inquiry. As such, CT is a liberating force in education and a powerful resource in one's personal and civic life. While not synonymous with good thinking, CT is a pervasive and self-rectifying human phenomenon" (Facione, 2011, p. 26).

The experts assented that $\mathrm{CT}$ is compound of two interwoven dimensions: cognitive skills (interpretation, analysis, evaluation, inference, explanation and self-regulation) and dispositions (inquisitive, judicious, open-minded, analytical, systematic, truthseeking, confident in reason).

Ennis (1996) considered that the disposition to be well-informed and the disposition to take a position when evidence and reasons are sufficient to do so, need to be included in our goals for teaching critical thinking, as well (p. 170). Norris (1985) asserts that students need not only the ability, but also a critical spirit. Nevertheless, "critical thinking skills are no substitute for experience, common sense, and sound knowledge of subject matter" (p.44) because CT is sensitive to context, prior knowledge and assumptions.

He highlights that research on critical thinking has shown that CT is not an educational option; it is in fact an educational ideal and a moral right. However, Chaffee (1992) replies that "despite the fact that teachers aspire to teach critical thinking as an educational ideal, critical thinking is rarely taught explicitly and systematically at any level of education" (p.2) and college instruction still focuses on the lowest cognitive level of knowledge, such as memorizing and remembering information, while higher intellectual operations, for instance, application, synthesis and evaluation, are usually ignored.

So far the definitions of CT implicate cognitive skills and dispositions. Nevertheless, Bailin, Case, Coombs and Daniels (1999a) consider that viewing CT in terms of cognitive skills is relatively benign, but this conception brings some difficulties in education. First, it is based on a conception of skill as a generic operation, which implies that these skills can be applied in any context regardless of background knowledge. In fact, "background knowledge in the particular area is a precondition for critical thinking to take place" (p. 271). For instance, interpreting a graph is a very different endeavor from interpreting a play, as it depends mainly on the context where such interpretation is occurring. Second, it involves the existence of certain mental processes or cognitive operations. Finally, it implies proficiency using these processes, which may result in terms of procedures or steps.

Viewing CT as mental processes is also misleading because teachers and educators can only identify them by their products; "observing them directly is a logical impossibility" (p. 273). Hence, it is more accurate to talk about enabling students to fulfill meaning conventions and standards to demonstrate the quality of their thinking when making decisions, arguing, solving problems, etc.

According to Bailin, Case, Coombs and Daniels (1999b), CT is characterized by the quality of thinking, not by mental or psychological processes. Thus, they claim to regard a critical thinker in terms of intellectual resources. "These intellectual resources are of five kinds: background knowledge, operational knowledge of standards of good thinking, knowledge of key critical concepts, heuristics (strategies, procedures, etc.) and habits of mind" (p. 
290).

First of all, background knowledge because CT occurs in the context of already existing concepts, beliefs, values and ways of acting. In this matter, Bailin et al. (1999b) coincide with Norris (1985) in the fact that CT is sensitive to context and it requires individuals to apply their knowledge as well as their common sense and experience.

Second, operational knowledge of standards of good thinking enables individuals to use standards of argumentation, rules of logic, standards of practical deliberation, standards governing inquiry and justification in specialized areas of study, standards for judging intellectual products, etc. (Bailin et al., 1999b, p. 291).

Third, knowledge of key critical concepts empowers critical thinkers to appraise intellectual products, i.e. arguments, statements, definitions, by differentiating premises, conclusions, assumptions; metaphorical and literal language; esthetic, moral and prudential judgments in order to carry out responsible deliberation (p. 293).

Fourth, heuristics (strategies, procedures, etc.) guide persons to deal with a wide range of thinking tasks which may involve problem-solving, decision-making, reflective learning, deliberation, etc.

Finally, habits of mind, because "having intellectual resources for critical thinking does not, by itself, make one a critical thinker" (p. 294). One must have adequate attitudes, dispositions and habits of mind, such as respect for reasons and truth, respect for high-quality products and performances, an inquiring attitude, open-mindedness, fair-mindedness, independent-mindedness, respect for others in group inquiry and deliberation, respect for legitimate intellectual authority, and an intellectual work-ethic, so as to use a variety of intellectual resources in the exercise of good judgement and CT in a more self-conscious way.

To conclude, Bailin et al. (1999a) argue that proficiency in CT involves principles of thinking in particular areas, which gives rise to the idea of CT as a domain-specific mode of thinking.

\subsection{Latin American Authors}

CT is a subject of reflection in Latin America that has been discussed in three lines: a political and ideological reflection; a pedagogical and educational reflection; a reflection on teaching, fostering and assessing critical thinking in education (Velez, 2013). First, it is political and ideological due to its main concern of reinterpreting forthcoming events in Latin America such as social, economic, cultural, political and environmental conflicts, in order to propose new courses of action. Second, it is pedagogical and educational owing to Freire's pervasive inspiration. He postulates education as the praxis of freedom through a humanistic and transforming pedagogy that seeks out to emancipate individuals from oppression and slavery (Freire, 2005). Finally, it is a reflection that deals with infusing and integrating $\mathrm{CT}$ across the education system, which is the main focus of this paper.

Mota (2010) acknowledges the importance of promoting CT in education. However, she emphasizes that many teachers implement teaching and learning strategies that are not always adequate to develop CT skills because it seems that education objectives are still grounded on a transmissionist model. She asserts that argumentation, via analysis, evaluation and reconstruction of controversial topics, contribute to nurture critical and reflective thinking in students.

Crosseti, Bittencourt, Schaurich, Tanccini and Antunes (2009) identified the five most referred strategies for teaching critical thinking in nursing - which may also be applied in EFL - namely questioning, case studies, online teaching and interactive learning, concept maps, and teaching based on problem solving.

Gonzalez (2006) supports this idea of conceiving the teaching of CT within specific discipline frameworks as every subject matter brings along distinct criteria or standards that become referents to judge the quality of our thinking. That is to say, every field of knowledge is a particular mode of thinking. For instance, the content and speech pertaining to physics is a mode of thinking by the physicists.

As a matter of fact, Tamayo (2013), one of the main authors in Latin America regarding CT and its constituents, views $\mathrm{CT}$ as a domain specific ability that can be developed in education within all the different branches of knowledge studied, as well as through inter and cross-disciplinary studies. He expresses, however, that it is more pertinent to adopt an integrating and inter-disciplinary position towards $\mathrm{CT}$ in such a way that it becomes a conceptual and methodological tool, an intellectual resource, and a strategy for individual and collective emancipation, which is permeated by educational processes and knowledge production (Tamayo, 2014).

He argues that there are four core constituents of CT, namely argumentation, metacognition, problem-solving and emotions. Firstly, argumentation has a strong relationship with language and its purpose is to convince with reasons or persuade through emotional resources. It involves cognitive and communicative abilities, intentions, discussion topics, and the sociocultural context. Secondly, metacognition is the knowledge and control over 
one's own thinking process so as to monitor, evaluate and plan one's own learning. It involves metacognitive knowledge, which refers to the knowledge of your own capacities and cognitive processes; metacognitive awareness, which refers to the knowledge students have about the purposes of class tasks and instructions; metacognitive regulation (or control), which refers to the set of activities that help students self-control their cognitive achievements and it is related to learner's decisions before (planning), while (monitoring) and after (evaluating) carrying out certain learning task (Tamayo, 2006). Thirdly, problem-solving helps students develop an ability to determine crucial elements in certain given input, to debate, to critique, to apply new knowledge and skills as well as to develop attitudes and dispositions towards social phenomena, dilemmas, and knowledge. Lastly, emotions, motivation and affection, are involved in learning domain-specific knowledge all along.

\subsection{EFL Authors}

$\mathrm{CT}$ is one of the contemporary education concepts that should be better understood by EFL teachers so that it is oriented towards the achievement of L2 skills while shaping up autonomous learners, who are able to evaluate their own learning process critically (Delmastro \& Balada, 2012, p. 27). Numrich (2011a) asserts that CT is an essential aspect to teaching language because it focuses on inferring and articulating meaning, rather than just on recalling and reproducing knowledge. She acknowledges that the two main camps in the CT world - the philosophers and the psychologists - contribute important elements for planning classroom activities. On the one hand, a philosophical stance, based on reasoning and evidence to evaluate claims, encourages teachers to choose material that does not represent their own point of view so that they become the first model of a critical thinker to their students (Numrich, 2011b). On the other hand, a psychological stance, based on cognition and mental processes to solve problems, make decisions and learn new concepts, provides an essential reference in the use of cognitive levels in the questioning area.

Puchta (2012) stresses that thinking skills and foreign/second language are highly benefitted from tasks that have a real-world purpose such as problem-solving, decision-making, thinking about the consequences of one's own or other people's actions and so on (p. 16). This kind of activities promotes communication and places priority on content and meaning rather than on structure. As a matter of fact, language acquisition occurs when language is used for what it was designed for, communication (Krashen, 1982, p. 7).

Pineda Baez (2004) implemented didactic units that involved critical thinking skills in a qualitative case study. She found that students made associations and interpretations using their prior knowledge from their fields of study, personal beliefs, values and experiences, as a platform for the new construction of meanings (p. 73). Besides, teachers play an important role in the metacognitive processes students have of their learning by encouraging them to go beyond superficial messages, and to reflect on what they understand, which are essential to monitor and control someone's thinking. When teachers provided thought-provoking feedback in their lessons, students tended to elaborate more on their ideas. She concluded that the implementations of those tasks impacted students' development of language competence in terms of lexical and discursive competence. However, "the learning of a language, as well as the development of critical thinking, is a long-term task that entails continuous practice and reflection from both teachers and learners"(p. 74).

Mok (2010) agrees with Pineda Baez on the role English Language Teachers have on the development of students' critical thinking. In spite of being aware of the importance of teaching how to think critically, teachers in her study admitted that they needed support and a specific professional development plan related to the implementation of critical thinking in EFL, which also addresses Pineda's (2004) call for educators to examine their own contexts and reformulate their learning outcomes in order to promote the development of a communicative competence in English as a foreign language along with the promotion of critical thinking.

Alana (2010) claims that the term Critical Thinking still generates confusion, regarding its meaning and application, among Foreign Language faculty and students. In her study, professors focused on questioning, data verification and avoidance of bias and prejudice, whereas students focused on analysis from different points of view. The latter also argued that there is deficiency of critical thinking in memorizing vocabulary and grammar rules and there are not sufficient opportunities to think critically in the first stages of learning a foreign language. They affirm that critical thinking is more likely to take place in advanced levels because there are more discussions, reflections, comments and opinions shared with their classmates and teachers.

Martinez (2011) asserts that when students are challenged to express their thinking, they make a bigger effort to communicate their messages including proper vocabulary and syntax according to the kind of thinking they want to transmit, which eventually turns out to influence on their motivation positively due to the acknowledgement of their personal voice in class. He poses a question on whether bilingual and monolingual students go through the same process when thinking critically, which goes hand in hand with Pineda's (2004) and Murcia's (2012) query 
on what previous L1 (mother tongue) academic experiences students bring with them, how they can be linked to L2 (second language, or foreign language) in order to facilitate language development (p. 77), along with how foreign language competence and the use of complex structures are interwoven with critical thinking (Martinez, 2011).

Maibodi and Fahim (2012) respond that L2 learners may have well developed abilities in their L1 but they are willing to transfer those skills into the language classroom. In addition, "using the language and knowing the meaning do not lead the learners to be proficient. Instead, they need to display creative and critical thinking through the language to express their ideas creatively and critically" (p. 38). Murcia (2012) supports this argument as the necessity to use L2 and to think critically about the topics to be discussed in class promotes the usage of the target language (L2), and at the same time, it requires to use cross-disciplinary critical thinking skills such as interpretation, analysis, inference, evaluation, explanation and self-regulation (Facione, 2011).

In the arena of classroom strategies that foster CT in EFL, Delmastro and Balada (2012) compiled nine strategies that were favorably evaluated by teachers and learners in their study: a) The Big Question, which aims to search for data and evidence and then analyze such information; b) Matching Exercise, which expresses cause and effect relationships; c) Color Highlighting, which establishes differences between facts and opinions, main ideas and secondary ideas, pros and cons, data and examples; d) Fishbone Diagram (Ishikawa), which expresses causality; e) T-chart, which differentiates facts and opinions, establishes comparisons, presents pros and cons arguments; f) The Question Formulation Technique, which orients the reflection on a given input; g) Venn Diagram, which establishes similarities and differences, comparison and contrast; h) Concept map, which selects, organizes and represents information ; i) Discussion sheet, which organizes and evaluates information.

Broadly speaking, there is apparent consensus that reflecting, incorporating, fostering and evaluating CT can strengthen students' fluency meaningfully in order to reach higher levels of proficiency in L1 and L2. In fact, EFL teachers and scholars acknowledge the importance and impact that critical thinking can have over language proficiency because "CT tends to expand students' learning experience and makes language learning deeper and more meaningful"(Zhao, Pandian, \& Singh, 2016, p. 14). Nonetheless, it seems that English language teachers and language learners are not familiar with the promotion of critical thinking in EFL (Mok, 2010; Alana, 2010; Murcia, 2012; Ketabi, Zabihi, \& Ghadiri, 2012). Therefore, further research on teachers' understanding of, and attitudes towards, critical thinking instruction in different EFL contexts is required to consolidate a solid comprehension of what critical thinking in language classes implies.

\section{Method}

This qualitative research was conducted as a descriptive comprehensive study bearing in mind that the conceptions of CT are framed in the study of meanings, senses and expectations of human actions (Jimenez \& Tejada, 2007). CT was addressed as a whole based on the data provided by the participants in order to comprehend its particularities in EFL. Consequently, this study was grounded on a holistic, inductive, ideographic approach, in which the researcher got involved in a personal discipline, adopting a disciplined subjectivity that required self-awareness, meticulous examination, constant reflection and recursive analysis (López Noguero, 2002, p. 3).

Therefore, Content Analysis, as a qualitative process of analysis and source of information, interpretation and conclusions (Hurtado, 2006), was the method adopted to comprehend the conceptions of CT in EFL from university English Teachers in Manizales. Content Analysis has the capacity to host content that being read and interpreted properly opens pathways to new knowledge of diverse social life aspects and phenomena (Abela, 2002). Moreover, Content Analysis is not merely descriptive, but its main function is inferential.

\subsection{Participants}

Ten English teachers from five universities in Manizales, Colombia, were invited to participate in this study. All of them held Bachelor's degrees in Modern Languages. Eight of them held Master's degrees: two in Education, two in TEFL, one in Virtual Learning Environments, one in Education Technology Management, one in Sciences Teaching, one in Translation and Interpreting. Four of them were older than 40 years old, two were between 30 and 40, four were between 20 and 29; the youngest participant was 26. All of them had over three years of experience teaching English as a Foreign Language, three had more than six-year EFL teaching experience, and five had more than ten years of experience teaching EFL. Five of them expressed not having been trained on CT, two participated in CT workshops, two studied CT in a seminar from their Master's degree, and one was trained on CT in an ELT seminar. Eight teachers belonged to private universities and two to public universities. 


\subsection{Data Collection}

Data was gathered in three phases: a) individual semi-structured interview; b) online survey; c) final questionnaire. First, all participants were interviewed individually in the universities they worked at. They knew this research dealt with EFL but they were not aware of the CT component before conducting the interview. This instrument sought to have a first approach to teachers' conceptions, beliefs, opinions or prior knowledge of CT and its application in the EFL classroom. Second, an online survey was designed in google forms and sent to the participants' emails. The survey included some Yes/No questions in which teachers had to justify their answers. In spite of being susceptible to quantification, priority was given to the explanation or supporting ideas provided by the participants. This survey intended to relate existing stances of CT to teachers' experience and expertise. Lastly, the final questionnaire explored the possibility to deepen on a conception of CT in EFL as a domain-specific mode of thinking. Therefore, each instrument was designed to explore the conceptions of CT from a general perspective to a more specific conception of CT in EFL

\subsection{Data Analysis}

The analysis implemented was based on Mayring (2000) inductive model whose main interest is to develop categories as near as possible to the material to be interpreted. These categories are reviewed and eventually reduced until getting the main category. Pinuel (2002) states that the category selection constructs the representations that enable the object of analysis to be looked through.

The software Atlas.ti, recommended by Mayring (2000), Abela (2002), and Piñuel (20012, was the computer program used with the purpose of analyzing the data derived from the interview, the online survey and the final questionnaire. This software consolidates large volumes of information and keeps track of mind maps, annotations, notes, codes and memos, relying on the researcher autonomy to identify emergent categories based on his education, the material of analysis and the literature review (Porta \& Silva, 2003).

The units of analysis for this study were sentences, phrases, paragraphs and topics susceptible to being expressed in categories and sub-categories. The participants' responses were assembled and integrated, prioritizing those interventions with common components and more frequency to be at the top of the conception in each of the categories, and those with less frequency to be on the closing line of the conception.

\section{Results}

Phrases, stretches of language and topics brought up by the participants were analyzed and integrated along the three instruments. As a result, the following categories emerged: Critical Thinking in EFL; Critical Thinker in EFL; Promotion of Critical Thinking in EFL; Assessment of Critical Thinking in EFL.

\subsection{Critical Thinking in EFL}

$\mathrm{CT}$ is associated with the ability to analyze information, reason out, and consider different points of view. It is a thinking skill to solve problems and comprises higher order thinking skills to process information, take a stand on diverse life situations, and achieve goals. It helps to recognize differences, virtues, pros and cons.

CT is also considered as generic thinking skills that improve rational processes and the development of problem-solving skills, either in L1 or L2. Its specific application in EFL lies in the analysis and reflection of one's own teaching and learning process.

Consequently, teachers' conceptions of CT in EFL are generally related to the definition suggested by the panel of experts in the Delphi report (Facione, 1990), in terms of involving core thinking skills such as interpretation, analysis, inference and self-regulation for the purpose of solving problems.

\subsection{Critical Thinker in EFL}

A critical thinker is analytical, impartial, respectful of other standpoints, and reflective. They nurture their thinking through education, training and reading. In addition, they are proactive, self-confident and autonomous. They know exactly what they want, are good observers, open-minded, bold and sensitive to context. These traits empower students to be inquisitive, self-critical and active agents of their own learning process. Consequently, they develop better communicative skills and learn to understand ways of thinking from other cultures.

A critical thinker in EFL is characterized by being an active learner who constantly asks questions and searches for information to establish relationships between L2 learning and other aspects of his daily life. It is a person who is capable of analyzing and organizing his thoughts to express them by speaking and writing, always has something to say in relation to the topics dealt in class, and puts into practice what has been learned.

Exposure to CT in L1 is an advantage for CT in EFL, but it is not a prerequisite. However, for the purpose of 
developing CT in EFL, teachers must be role models of critical thinkers, provide guidelines and plan activities that provide opportunities for students to think critically. Moreover, students must have knowledge related to the topics to be dealt.

To sum up, a critical thinker in EFL has proper dispositions and attitudes towards life, learning and decision-making, similar to those addressed by the panel of experts (Facione, 2011). In addition, a critical thinker in EFL makes use of his prior knowledge, his common sense and experience, because CT cannot occur in a vacuum (Norris, 1985).

\subsection{Promotion of Critical Thinking in EFL}

The main challenge for CT in EFL lies in the fact that English teachers do not have enough training on this area. Seeminingly, there are no professional learning communities, schools or groups leading this process in EFL. CT is widely known in other fields rather than in EFL. A constraint expressed consists of shortage of time to go through topics and content, mainly because CT is not part of the syllabus, the lesson planning or the curriculum. Students' low command of English to convey their ideas is another constraint for CT in EFL. In fact, teachers from this study emphasized that students hardly develop CT in their mother tongue since education policies focus on tests and international exams, instead of fostering thinking.

On the one hand, most teachers stated that CT is hardly ever promoted in the EFL classroom due to lack of clarity related to the concept. Furthermore, teachers expressed that CT in EFL is subject to having a critical thinker as a teacher and at the same time having clear institutional policies to promote it. On the other hand, some teachers averred that $\mathrm{CT}$ is usually promoted through oral and written activities that focus on expanding information and considered that EFL instructors use implicit CT elements in their lessons, but it is often unconsciously.

Teachers agree on the importance of CT as a component of EFL instruction because it is considered to help students become autonomous and make effective daily decisions in order to construct knowledge, propose practical and effective solutions to different life situations and reflect on the way they learn. Nonetheless, CT has been practically unnoticed in Foreign Language Teaching (FLT) programs. These programs emphasize on the development of linguistic competence, grammar teaching, pedagogy and methodology, mainly based on theory rather than on practice. In fact, teachers asserted that it is a real challenge for FLT programs to foster CT in EFL teachers to be.

Thus, promoting $\mathrm{CT}$ in EFL requires teachers to think teaching beyond grammar structures and vocabulary, and focus on fostering thinking, creativity, autonomous learning, decision-making and self-evaluation. Likewise, educators should provide opportunities for students to be creative and get on a real communicative environment, in which students express their points of view about topics discussed in class. Task-based and project-based activities provide learning environments that foster autonomous learning, active participation, decision-making and reflection on one's own learning process and L2 progress.

$\mathrm{CT}$ is an ongoing enterprise that is favored by reading, questioning, and analysis of contemporary topics. Strategies to foster CT in EFL can be implemented at any stage of language learning, from beginner to advanced levels, but the level of complexity of the tasks will vary depending on the command of the language. The best strategies to promote CT in EFL suggested by teachers were debates, round tables, roleplays, oral discussions about topics of interest, case studies, project-based activities, presentations, essays, decision-making activities, problem-solving tasks, and self-evaluation activities. The Communicative Approach is considered to be the most appropriate method because it generates communication environments to exchange ideas.

Teachers believe that CT should play a more important role in the EFL curriculum for it is not only necessary to learn linguistic codes to communicate, but also to make use of such codes to argue, propose ideas, and solve daily life problems. CT can strongly boost students' linguistic and communicative competence, seeing that it encourages students to make an effort to extend their ideas and express their points of view. As a result, L2 turns into a more functional means to argue and perform more effectively in our social, personal and professional life.

Finally, they punctuated the need to open academic discussion spaces so as to reformulate objectives, methodologies and curricula. Consequently, EFL will serve not only as a setting to develop L2 communicative competence, but also as a scenario to foster critical thinking in EFL learners.

\subsection{Assessment of Critical Thinking in EFL}

Generally speaking, teachers asserted that EFL assesses the formal use of language in terms of grammar and vocabulary, but no CT. They expressed that CT itself is not assessable in EFL. Instead, clarity of ideas would be assessed in terms of use of language, pronunciation, spelling, punctuation, coherence, cohesion, and fluency 
when expressing ideas and opinions. They conceived CT as a non-assessable component for EFL due to the fact that opinions and ideas belong to every person. Therefore, students' points of view are valid, and EFL teachers assess the way learners use different features of $\mathrm{L} 2$ when expressing their thoughts.

CT in EFL may be assessed through debates, interviews, presentations, compositions, cooperative tasks, self-assessment and self-evaluation, role plays, and project-based activities. Still, teachers also reckon that CT in EFL is assessed subjectively and indirectly.

In terms of testing, teachers considered that EFL exams do not normally contain CT-centered sections and feel they are far from designing exams that test CT formally. Nevertheless, the written composition section and oral exams are thought to be ideal for students to explain and argue their ideas. Moreover, teachers expressed that there are some reading texts and listening exercises that test students' capacity to infer and analyze content. In addition, International exams such as PET, TOEFL and IELTS are thought to be exams that may be close to test $\mathrm{CT}$ in EFL.

\section{Discussion}

Even though ten university EFL teachers are only a microcosm of the EFL community, it is impressive to recognize that studies in some Asian (Ketabi et al., 2012; Mok, 2010) and Latin American countries (Pineda Baez, 2004; Pineda Báez, C., Pardo, A. N., \& Téllez, M. F. 2010; Murcia, 2012) agree with this study on the need and challenge to educate and train teachers to develop CT in EFL, to open academic spaces to discuss and intervene educational processes to reformulate the curriculum and learning outcomes, in order to approach CT promotion in EFL with academic rigor as well as with social and educational responsibility.

For instance, there is a seeming equivalence in this study between CT and simple expression of ideas, which, from the author's perspective, is clearly misleading, seeing that "excellence in thought must be systematically cultivated ... and it requires rigorous standards of excellence and mindful command of their use" (Paul \& Elder, 2007). Furthermore, Bailin et al. (1999a) claim that teachers should guide learners to fulfill standards of performance or intellectual resources to demonstrate quality in thinking.

As a matter of fact, teachers guide students towards planning, monitoring and evaluating their own learning process and their own thinking, by fostering metacognition in the classroom, active and autonomous learning, emotions, motivations and affections involved in the teaching and learning process of every specific field or subject matter, in our case, EFL. Thus, the teacher's role is to design and manage learning experiences that encourage and guide students towards the construction of their own knowledge (Gonzalez, 2006, p. 46).

The importance of CT in EFL is not born out of research, literature or global trends. It is born out of the main international referent for learning, teaching and assessing languages and it is usually unperceived by most of the EFL community. It is born out of the Common European Framework of Reference (CEFR) for Languages (Council of Europe, 2001), in which an independent user (B1-B2) develops a clear argument, expanding and supporting his/her points of view at some length with subsidiary points and relevant examples, constructs a chain of reasoned argument, explains a viewpoint on a topical issue giving the advantages and disadvantages of various options (p. 59); gives reasons in support of or against a particular point of view (p. 27, 60, 62); obtains information, ideas and opinions from different sources (p. 239), evaluates alternative proposals, makes and responds to hypotheses (p. 77); participates actively in routine and non-routine discussions (p.78), speculates about causes, consequences and hypothetical situations (p. 232); helps along the progress of work by inviting others to join in, say what they think (p. 79) in order to reach a goal, copes linguistically to negotiate a solution to a dispute (p. 80), evaluates different ideas and solutions to a problem, synthesizes information and arguments from a number of sources (p. 232); corrects slips and errors if he/she becomes conscious of them or if they have led to misunderstandings, makes notes of "favorite mistakes" and consciously monitor speech for it/them, corrects mix-ups with tenses and expressions that lead to misunderstandings (p. 65); uses circumlocution and paraphrase to cover gaps in vocabulary and structure, defines the features of something concrete for which he/she cannot remember the word, plans what is to be said and the means to say it, considering the effect on the recipient/s, rehearses and tries out new combinations and expressions, inviting feedback (p. 64).

\section{Conclusion}

This study of the conceptions of critical thinking held by university EFL teachers in Manizales may have transcended from these teachers' beliefs towards a collective construction of knowledge regarding some of the constituent dimensions of CT in EFL. The dimensions that can be inferred and applied to CT in EFL are creativity, problem-solving, decision-making, autonomous learning and metacognition. Moreover, it is significant to incorporate dimensions such as argumentation, motivations, affections and emotions expounded by 
Tamayo (2014).

CT in EFL should be approached from a perspective that integrates the contributions of different fields of knowledge such as psychology, philosophy, pedagogy, didactics, constructivism and others. As a result, CT in EFL could be defined as a set of conceptual, methodological, criteriological and contextual considerations that integrates thinking skills, dispositions, attitudes, intellectual resources and pedagogical assistance. It affects communicative competence, creativity, argumentation, problem-solving, decision-making, autonomous learning, metacognition and emotions. It is oriented through a communicative approach, including task-based and project-based instruction, in order to take ownership of information, construct knowledge, take individual and collective action with the purpose of shaping up ethical citizens who are committed to the common good and the dignity of others.

In addition to thinking skills, dispositions, intellectual resources, metacognition and other elements found in the literature, students must be exposed to opportunities to think critically. Instead of applying standardized multiple-choice tests with one correct answer, EFL learners should be exposed to discussion activities, tasks, and tests that evaluate their performance based on individual and cooperative criteria, with open questions that require students to put into practice their quality of thought, argumentation, analysis, synthesis, explanation, evaluation, new ideas, use of language, facts, opinions, thesis statements, evidences, supporting information, examples, use of connectors, proper register, etc., focusing on content, meaning, standpoints, structures and lexical resource.

\section{References}

Abela, J. A. (2002). Las técnicas de análisis de contenido: una revisión actualizada. Retrieved from http://anthropostudio.com/wp-content/uploads/2014/07/Andr\%C3\%A9u-J.-2000.-Las-t\%C3\%A9cnicas-dean\% $3 \%$ A 1 lisis-de-contenido-una-revisi\% $\%$ C3\%B3n-actualizada..pdf

Alana, A. (2010). El Pensamiento Crítico y la Cultura en los Programas de Lenguas Extranjeras. (Electronic Thesis or Dissertation). Retrieved from https://etd.ohiolink.edu/

Bailin, S., Case, R., Coombs, J. R., \& Daniels, L. B. (1999a). Common misconceptions of critical thinking. Journal of Curriculum Studies, 31(3), 269-283. http://dx.doi.org/10.1080/002202799183124

Bailin, S., Case, R., Coombs, J. R., \& Daniels, L. B. (1999b). Conceptualizing critical thinking. Journal of curriculum studies, 31(3), 285-302. http://dx.doi.org/10.1080/002202799183133

Chaffee, J. (1992). Critical thinking skills: The cornerstone of developmental education. Journal of Developmental Education, 15(3), 2.

Council of Europe. (2001). Common European framework of reference for languages. Learning, Teaching and Evaluation. . Retrieved from https://www.coe.int/t/dg4/linguistic/Source/Framework_EN.pdf

Crossetti, M. D. G. O., Bittencourt, G. K. G. D., Schaurich, D., Tanccini, T., \& Antunes, M. (2009). Estratégias de ensino das habilidades do pensamento crítico na enfermagem. Revista gaúcha de enfermagem. Porto Alegre. Vol. 30, n. 4 (dez. 2009), pp. 732-741. Retrieved from http://hdl.handle.net/10183/28240

Delmastro, A. L., \& Balada, E. (2012). Modelo y Estrategias para la Promoción del Pensamiento Crítico en el Aula de Lenguas Extranjeras. Synergies Venezuela, 7, 25-37.

Ennis, R. H. (1996). Critical thinking dispositions: Their nature and assessability. Informal Logic, 18(2). http://dx.doi.org/10.22329/il.v18i2.2378

Facione, P. A. (1990). The Delphi Report. Executive Summary-Critical Thinking. A Statement of Expert Consensus for Purposes of Educational Assessment and Instruction. Millbrae, CA: California Academic Press. Retrieved from https://assessment.trinity.duke.edu/documents/Delphi_Report.pdf

Facione, P. A. (2011). Critical thinking: What it is and why it counts. Insight Assessment, 2007(1), 1-23. Retrieved from http://elementary.nrms.wikispaces.net/file/view/Critical+Thinking+and+Why+(2).pdf

Freire, P. (2005). Pedagogía del oprimido. Siglo xxi.

González, J. (2006). Discernimiento, Evolución del pensamiento crítico en la educación superior, El proyecto de la Universidad Icesi. Universidad ICESI. Cali, Colombia, Septiembre. Retrieved from https://repository.icesi.edu.co/biblioteca_digital/bitstream/10906/1017/4/gonzalez_discernimiento_evolucio n_2006.pdf

Hurtado, J. C. T. (2006). Investigación cualitativa: comprender y actuar. Editorial La Muralla. 
Jiménez, B., \& Tejada, J. (2007). Procesos y métodos de investigación. J. Tejada y V. Giménez (coords.), Formación de formadores. Escenario institucional. Madrid: ites-Paraninfo. Retrieved from http://abacoenred.mayfirst.org/wp-content/uploads/2015/10/Procesos_y_metodos_de_investigacion.pdf

Ketabi, S., Zabihi, R., \& Ghadiri, M. (2012). Critical thinking across the ELT curriculum: A mixed methods approach to analyzing L2 teachers' attitudes towards critical thinking instruction. International journal of research studies in education, 2(3).

Krashen, S. (1982). Principles and practice in second language acquisition. Retrieved from $\mathrm{http}: / /$ citeseerx.ist.psu.edu/viewdoc/download?doi=10.1.1.463.8762\&rep=rep1\&type=pdf

López Noguero, F. (2002). El análisis de contenido como método de investigación. XXI. Revista de Educación, (4), 167-180. Retrieved from http://uhu.es/publicaciones/ojs/index.php/xxi/article/view/610

Maibodi, A. H., \& Fahim, M. (2012). The Impact of Critical Thinking in EFL/ESL Literacy. The Iranian EFL Journal, 32(1), 24.

Martínez Verdesoto, C. M. (2011). Tres actividades de pensamiento crítico: debate, solución de problemas y dramatización aplicadas a una clase de inglés como lengua extranjera en una universidad privada ecuatoriana (Master's thesis, Quito: USFQ, 2011). Retrieved from http://repositorio.usfq.edu.ec/handle/23000/811

Mayring, P. (2000). Qualitative Content Analysis. Forum Qualitative Sozialforschung / Forum: Qualitative Social Research, 1(2). Retrieved from http://www.qualitative-research.net/index.php/fqs/article/view/1089

Mok, J. (2010). The new role of English language teachers: developing students' critical thinking in Hong Kong secondary school classrooms. The Asian EFL Journal Quarterly, 12(2), 262-287.

Mota de Cabrera, C. (2010). Desarrollo del pensamiento crítico a través del discurso argumentativo: Una experiencia pedagógica en un curso de lectura y escritura. Entre lenguas, 15, 11-23.

Murcia Quintero, D. (2012). Critical thinking applied in communicative tasks: An innovative pedagogical practice in the EFL classroom through action research (Bachelor's thesis, Pereira: Universidad Tecnológica de Pereira). http://hdl.handle.net/11059/2602

Norris, S. P. (1985). Synthesis of research on critical thinking. Educational Leadership, 42(8), 40-45.

Numrich, C. (2011a). Critical Thinking part $1 \& 2$ : The importance of Critical Thinking. In Pearson ELT. Pearson Longman.

Numrich, C. (2011b). Critical Thinking part 2: The importance of Critical Thinking. In Pearson ELT. Pearson Longman.

Paul, R., \& Elder, L. (2007). The Miniature Guide to Critical Thinking: Concepts \& Tools. Foundation Critical Thinking.

Pineda Báez, C., Pardo, A. N., \& Téllez, M. F. (2010). Unidades didácticas relacionadas con pensamiento crítico: una alternativa innovadora para fomentar la competencia lingüistica en la lengua extranjera Apuntes Contables, (5). Retrieved from http://190.7.110.123/pdf/5_revistaApuntesContables/documentosApuntesContables/AC\%205/Pineda,Nunez yTellez.pdf

Piñuel R., J. L. (2002). Epistemología, metodología y técnicas del análisis de contenido. Sociolinguistic Studies, $3(1), 1-42$.

Porta, L., \& Silva, M. (2003). La investigación cualitativa: El Análisis de Contenido en la investigación educativa. Red Nacional Argentina de Documentación E Información Educativa Http://www. Uccor. Edu. ar/paginas/REDUC/porta. Pdf (Retrieved: 1-2-2010). Retrieved from http://anthropostudio.com/wp-content/uploads/2015/04/Luis-Porta.-La-investigaci\%C3\%B3n-cualitativa.-El -An\%C3\%A1 lisis-de-Contenido-en-la-investigaci\%C3\%B3n-educativa..pdf

Puchta, H. (2012). Developing Thinking Skills in the Young Learners' Classroom. Cambridge: Cambridge UP. Retrieved from http://static.cambridge.org.br/upload/events/00002748.pdf

Tamayo, O. E. (2006). La metacognición en los modelos para la enseñanza y el aprendizaje de las ciencias. Los Bordes de La Pedagogía: Del Modelo a La Ruptura, 275-306.

Tamayo, O. E. (2013). La argumentación como constituyente del pensamiento crítico en niños. Hallazgos, 9(17). Retrieved from http://revistas.usantotomas.edu.co/index.php/hallazgos/article/viewFile/738/1018 
Tamayo, O. E. (2014). Pensamiento crítico dominio-específico en la didáctica de las ciencias. Tecné, Episteme Y Didaxis: Revista de La Facultad de Ciencia Y Tecnología, (36), 25-45. https://doi.org/10.17227/01213814.36ted25.45

Vélez G., C. F. (2013). Una reflexión interdisciplinar sobre el pensamiento crítico. (Unpublished article part of Doctoral Dissertation). Universidad de Caldas.

Zhao, C., Pandian, A., \& Singh, M. K. M. (2016). Instructional Strategies for Developing Critical Thinking in EFL Classrooms. English Language Teaching, 9(10), 14. http://dx.doi.org/10.5539/elt.v9n10p14

Zhou, J., Jiang, Y., \& Yao, Y. (2015). The Investigation on Critical Thinking Ability in EFL Reading Class. English Language Teaching, 8(1), 83-94. http://dx.doi.org/10.5539/elt.v8n1p83

\section{Copyrights}

Copyright for this article is retained by the author(s), with first publication rights granted to the journal.

This is an open-access article distributed under the terms and conditions of the Creative Commons Attribution license (http://creativecommons.org/licenses/by/4.0/). 